\title{
Sexual Aggression Against Women by Men Acquaintances: Attitudes and Experiences among Spanish University Students
}

\author{
Eric Sipsma \\ Universily of Amsterdam \\ Ignacio Montorio Cerrato \\ Autonomous University of Madrid
}

\author{
José-Antonio Carrobles Isabel \\ Autonomous University of Madrid
}

\author{
Walter Everaerd \\ University of Amsterdam
}

Extensive prior research has indicated that sexual assault is highly prevalent among American college students. The purpose of this study was to assess Spanish students' attitudes about forced sex and actual experiences with male-againstfernale sexual aggression (SA) at a major university campus. A date-rape story was presented whereupon scudents ( $N=$ 412) indicated the extent to which they thought forced sex was acceptable or unaceptable in ten hypothetical situations (Giarusso, Johnson, Gondchilds, \& Zellman, 1979). A second section examined whether a female or male Spanish student had experienced or engaged in a broad range of coercive sexual activities (Koss \& Oros, 1982). A third section elicited help-secking behavior in those cases where a female student had experienced unwanted sexual activity (Ogletree, 1993). It was hypothesized that students would differ in their acceptance of forced sex as a function of sex, branch and year of study, and actual experience with SA. Results showed that acceptance of forced sex was significantly related to sex, year of study and experience with SA. Results also revealed that $17.5 \%$ of all male students $(n=189)$ accepted forced sex and $33.2 \%$ of all female students $(n=223)$ had experienced some form of unwanted sexual activity; $7.7 \%$ of the women had experienced attempted or completed rape. Only $39 \%$ of those women victimized sought any form of help. The implications of these tindings for rape-prevention programs are discussed.

Key words: acquaintance rape, forced tex, rape myth, help-seeking behatior, prevention sexual aggression

\begin{abstract}
Tal y como han mostrado investigaciones previas, la agresión sexual es muy común entre los estudiantes universitarios estadounidenses. El objetivo de esta investigación es analizar tanto las actitudes de los estudiantes españoles hacia el sexo forzado como las experiencias reales de agresión sexual (AS) de los varones hacia las mujeres dentro del campus universitario. En una primera sesión, a los estudiantes $(N=412)$, se les presentaban diez situaciones hipotéticas de violación. Los participantes debian indicar hasta qué punto el sexo forzado les resultaba aceptable o inaceptable (Giarusso, Johnson, Goodchilds y Zellman, 1979). En una segunda sesión se pedía a varones y mujeres que indicasen si habian lenido experiencias o participado en actividades sexuales forzadas (Koss y Oros, 1982). También se investigó el comportamiento de búsqueda de ayuda de las alumnas en el caso de haber tenido una experiencia sexuai no deseada (Ogletree, 1993). La hipótesis establecía que habría diferencias significativas en el grado de aceptación del sexo forzado en función del sexo, de la carrera, del curso y de las experiencias reales de AS. Los resultados revelaron que la aceptación del sexo forzado se relacionaba significativamente con el sexo, el curso y la experiencia con AS. Los resultados también mostraron que el $17.5 \%$ de los varones $(n=189)$ aceptan el sexo forzado y el $33.2 \%$ de las alumnas $(n=223)$ han tenido alguna forma de actividad sexual no deseada. El $7.7 \%$ de las mujeres han vivido un intento de violación o una víolación. Solamente el $39 \%$ de las víctimas buscó algún tipo de ayuda. Por último, se comentan las implicaciones de estos resultados para la elaboración de programas preventivos de violación.
\end{abstract}

Palabras clave: violación entre conocidos, sexo torzado, mitos de violación, comportamiento de busqueda de ayuda, prevención de la agresión sexual

The authors wish to acknowledge the contributions of Julia Sebastián, Loreto Santé Abal, Beatriz Lucía Martínez, Javier Cabezuelo, Carmen Pozzo, María-José Bueno Casas, Ana Saéz, and Samuel Fernández. Carriba for their help in translating the questionnaire, their practical assistance during administration of the questiontaires, and their helpful and critical conments. We also thank Al Wallace for his careful reading and correction of previous drafts of this paper.

Correspondence to the first author should be addressed to the Rutgers Stichting, Business Unit Education \& Training, P.O. Box $9663,3506 \mathrm{GR}$, Utrecht, The Netherlands.

Address correspondence to the second iuthor at the Departamento de Psicología. Sección de Psicobiología y Psicología de la Salud. Universidad Autónoma de Madrid. Ciudad Universitaria Canto Blanco. 28049 Madrid (Spain). 
Ample evidence supports the premise that male sexual aggression (SA) against women among college students who know each other is a widespread phenomenon in the United States. In addition, extensive past empirical and epidemiological research reveal that sexual coercion is especially prevalent on college campuses (Abbey, 1991; Benson, Charlton, \& Goodhart, 1992; Dull \& Giacopassi, 1987; Frinter \& Rubinson, 1993; Koss, Gidycz, \& Wisniewski, 1987; Rapaport \& Burkhart, 1984). Koss et al. conducted a survey of 6,159 students $(3,187$ women and 2,972 men) from 32 different institutions of higher edtcation throughout the United States. Sexual contact (fondling or kissing after verbal pressure, misuse of authority, or use of threats or physical force) was reported by $14.4 \%$ of the women; scxual coercion (intercourse after verbal pressure or misuse of authority) by $11.9 \%$; attempted rape by $12.1 \%$; and rape by $15.4 \%$. Thus, from the age of 14 years, $27.5 \%$ of the college women surveyed had experienced an act that met the legal definition of attempted or completed rape. Among all the women, $53.7 \%$ reported some form of sexual victimization. After an extensive review of the literature, Shotland (1992) found that prevalence figures of sexual assault among college students range from 20 to $25 \%$, however, Lundberg-Love and Geffner (1989) reported that those figures vary between 15 and $44 \%$. Prevalence figures seem to depend on the age of subjects, methods of datacollection, and the criteria that are defined in the studies. Estimates of the percentage of rapes committed by a perpetrator who is known to the victim range from $50 \%$ (Rabkin, 1979) to $88 \%$ (Russell, 1984). Often these acquaintances are boyfriends and dates (Koss. Dinero, Seibel, \& Cox, 1988; Russell, 1984). Most studies about the frequency of sexual assault among college students indicate that 25 to $60 \%$ of college men have engaged in some form of sexually coercive behavior (Berkowitz, 1992; Check \& Malamuth, 1983; Koss et al., 1987; Rapaport \& Burkhart, 1984). Rapaport and Burkhart reported that $39 \%$ of the men sampled denied coercive involvement; $28 \%$ admitted having used a violent method at least once and $15 \%$ had forced a woman to have intercourse. Despite the high incidence of sexual assault identified in surveys, reports to clinicians, the police, and administrators are extremely low (Warshaw, 1988). Significant disruption in various aspects of a woman's life occurs after sexual coercion. Many researchers have reported long- and short-term effects of sexual coercion (e.g., Burgess \& Holmstrom, 1974; Ellis, 1994; Koss et al., 1988; Resick, Calhoun, Atkeson, \& Ellis, 1981). Many victims do not receive help (Warshaw, 1988).

Rape in which the assailant and victim know each other is called acquaintance rape. It seems likely that acquaintance rape and other forms of $\mathrm{SA}$ are rooted in the cultural stereotypes of men and women that dictate the way they are expected to interact socially and sexually (Burt, 1980; Gross, 1978; Malamuth, 1983). A number of researchers and theorists have suggested that sexual assault is the result of "normal" socialization processes that men experience and that the perpetrators' attitudes, beliefs, and socialization experiences are the core conditions which predispose a man to assault an acquaintance sexually or to believe that assault is justifiable (Benson et al., 1992; Gross, 1978; Margolin, Miller, \& Moran, 1989; Meuhlenhard \& McFall, 1981; Warshaw, 1988; Weis \& Borges, 1973). College men who rape are not necessarily pathological, but may be extending culturally supported sex role stereotypes. A man may be socialized to believe that women do not really mean it when they say "no" to sexual advances (Benson et al., 1992; Muehlenhard, Friedman, \& Thomas, 1985; Muehlenhard \& Hollabaugh, 1988). Rape myths distort the facts about and the violence involved in rape and inappropriately move the focus of attention from the crime and the assailant onto the victim and her behavior. These myths can include, for example: a) believing that the victim deserved to be assaulted; b) that women secretly desire to be raped; c) that a woman cannot be raped against her will; d) that no harm was done; e) that sexual assault never happened; f) or that rape is justifiable under certain circumstances (Aizenman \& Kelley, 1988; Burt, 1980; Malamuth, 1981; Warshaw, 1988). Many young people in the United States believe there is nothing wrong with forced sex between acquaintances (Aizenman \& Kelley, 1988; Check \& Malamuth, 1983; Fisher, 1986; Goodchilds, Zellman, Johnson, \& Giarusso, 1988; Koss, 1988; Muehlenhard et al., 1985). Meuhlenhard and McFall (1981) asked 100 college students to respond anonymously to questions about acceptable behavior in dating situations. Men reported that nonconsenting intercourse was justifiable when the woman initiated the date, when the man paid, or when the couple went to the man's apartment. Muehlenhard el al. (1985) found that the justifiability of rape also increased when a man misread the woman's cues and when it seemed that she "led him on." The inability and unwillingness of men who commit acquaintance rape to label their actions correctly has been documented in a number of studies (Peterson \& Franzese, 1987; Quackenbush, 1991). Adherence to rape-supportive attitudes has also been associated with actual experience as a perpetrator (Koss, Leonard, Beezley, \& Oros, 1985; Malamuth, 1981; Rapaport \& Burkhart, 1984).

The prevalence of myths concerning forcible sexual relations that have been observed among American college students has not been examined among Spanish college students. Moreover, there are no data about whether forced sex among students who are acquainted with each other occurs at any major Spanish university campus. The kind of sources sought by Spanish students after having been sexually victimized is also unknown.

The principal aim of this project is to determine to what extent and under which circumstances attitudes that support SA are accepted within a Spanish college population. We explore whether acceptability of forcible scxual contacts differs as a function of sex, branch of study, year of study, 
and actual experiences with forced sex. Secondly, we examine what kind of sexual activities are being carried out against the woman's will and to what extent SA is prevalent among Spanish students on a university campus. Furthermore, we also examine what percentage of the women seeks help after having been sexually victimized in some way. Which kind of help is sought, and for what kind of unwanted sexual experience? Finally, few studies have determined the relation between attitudes of individuals who had versus those who had not been involved in forced sex. When comparing students who have experienced some form of sexual violence with those who have not, what are their respective attitudes about condoning sexual violence? Are these attitudes generally more accepted or are they rejected? For this reason, we examine the relationship between acceptance of SA and unwanted sexual contacts experienced by women and SA perpetrated by men, respectively.

\section{Method}

\section{Participants}

A total of 432 Spanish students completed the questionnaire for this study. Our final sample size, after discarding incomplete or untrustworthy cases $(n=20)$, was 412. The final sample consisted of 223 women (54\%) and 189 men ( $46 \%$ ). The average age of the 118 first-year female students was 19.3 years $(S D=1.9)$; of the 109 first-year male students 19.5 years $(S D=2.6)$; of the 104 fourth-year female students, 23.2 years $(S D=1.4$ ); and of the 81 fourthyear male students 23.2 years $(S D=1.7)$. The subjects who participated in this study were entolled in one of the five following departments: 82 psychology students $(20 \%), 77$ economics students (19\%), 87 natural science students (21\%), 77 literature students (19\%), and 88 medicine students $(21 \%)$. In Table 1, the distribution of the final sample is presented.

Selection Procedure. The sampling goal of this study was to administer the questionnaires at a major university campus in Spain. Data for the present studly were therefore collected at the Autonomous University of Madrid, which has a student body of 35,000 . The aim was a sample of 500 students. Participants were recruited according to a cluster sampling design. Five departments (psychology, economics, medicine, literature, and natural science) were chosen because of the possible student diversity. In each branch of study, a first-year (junior) and fourth-year (senior) student class was recruited, resulting in a total of ten classes from five departments. Selection of the classes in the various branches of study was based on availability, size, and class composition. In each class, a minimum of 25 participants of both male and female students was required.

Appointments were made with the teachers beforehand to arrange the schedule. Students completed the questionnaires anonymously and voluntarily in class. The questionnaires were administered at the beginning of class or, if this was not possible, after class. The survey was presented at morning, midday, or cvening class and took 15 minutes to complete and was administered in May 1996. A male experimenter (M.D.) used a brief set of standard instructions to mitigate experimenter influence. Subjects were informed that the study concerned attitudes about and experiences with forcible sexual contacts occurring only between acquainted individuals. Furthermorc, they were told how many male and female participants were required in the class, and the time needed to complete the survey. In the instructions, they were requested to rate their own individual opinion and to avoid the tondency to give socially desirable answers. Students who did not wish to or were unable to participate were asked to remain in their seats and to do other work. This ensured that participants could complete their questionnaires individually. To avoid the possibility of students informing and discussing with other potential participants the purpose of the study, the experimenter carried out no debriefing after completion of the questionnaires. A short publication in the local university newspaper about the aim of this research, with a summary of the most important results, was promised at the time of administration. No student received class credit for participating.

\section{Instruments}

Survey Instrument. To collect the data, the self-report questionnaire entilled Questionnaire about Forcible Sexual Relations was divided into three sections. In the first section, respondents' attitudes about the acceptability of forcible sexual contacts were examined by administration of the Forcible Date Rape Scale (FDRS), developed by Giarusso, Johnson, Goodchilds, and Zeltman (1979). Then, their actual experiences with sexual aggression were explored with the Sexual Experiences Survey (SES), developed by Koss and Oros (1982). In the third section, a brief questionnaire by Ogletree (1993) was used to examine students' help-seeking behavior.

After obtaining background information such as age, sex, and branch and year of study, a brief introduction of the survey explained its content clearly, and some definitions were made explicit. Both male and fentale respondents were requested to complete the first two sections of the questionnaire: each section contained ten items. Only female respondents who in some way had been sexually victimized were requested to complete a third section, with eleven questions about assistance they might possibly have sought. In the survey introduction, the definition of a "known person" was "any person who may be a casual acquaintance up to a close intimate." A "Corced sexual relationship" was delïned as "iny form of nonconsenting sexual activity."

Three Spanish psychology postgraduates and a professor of Health and Biological Psychology carefully translated the FDRS, the SES, and the help-secking questionnaire into 
the Spanish language. The original English questionnaires were first translated into Spanish and then back into English to detect whether there were any erroneous translations. To increase the probability of truthful answers, after finishing the second or third section of the survey, participants were requested to rate on a 6-point scale how sincerely they had answered all questions: 6 was coded as totally sincere, 5 fairly sincere, 4 slightly sincere, and 1 totally insincere. Only subjects with scores of 5 or 6 were included for statistical analyses $(95.4 \%)$.

Date-Rape Vignette. In the present study, the authors wanted to be sure that all respondents understood that the questionnaire focused on forced sexual contacts between acquainted individuals. For this reason, we selected a hypothetical vignette from Davis, Peck, and Storment (1993). In this vignette, a date-situation is described in which a boy and a girl (Louis and Eva) who had been going steady for a long time were at a party. After leaving the party, the boy forces sexual contact with the girl (see Appendix A). A slight modification of the dating scenario utilized was necessary. The original English names of the characters were replaced by Spanish ones. After reading the date rape scenario, students were presented the FDRS.

Forcible Date Rape Scale. Questions from the FDRS, designed by Giarusso et al. (1979) were used to assess Spanish students' attitudes. Originally, they asked highschool students "Is it all right if a male holds a female down and physically forces her to engage in sexual intercourse?" in nine different circumstances, such as "when a girl gets a guy sexually excited" or "when a guy spends a lot of money on a girl," etc. Giarusso et al. required the students to respond yes or no. In order to give participants the chance to accept or reject items in differing degrees, we asked thern to rate their acceptability for each of ten circumstances on a 6-point rating scale, where 1 was rated definitely unacceptable, 2 fairly unacceptable, 3 slightly unacceptable and 6 definitely acceptable. Furthermore, we did not supply a no opinion rating point on this scale because the majority of students might not have a clear-cut opinion about all the situations, and, thus, a no opinion response could be chosen. The research could also lead subjects to choose this option instead of more sincere ones. The FDRS is shown in Appendix B.

Giarusso et al. (1979) investigated the unidimensionality of the FDRS. Results of a factor analysis of yes/no responses of high-school students yielded a single factor that the authors labeled "force." Fischer and Chen (1994) assessed the FDRS by exploratory factor analysis to detect whether a single factor described the covariance structure adequately using data from 341 female and 237 male college students. The propottion of variance accounted for by a single common factor solution was .636. A two-factor model was discarded after further inspection of the transformed factor loadings from both orthogonal and oblique rotations. Fischer and Chen concluded that the FDRS is unidimensional. A principal-components factor analysis of the FDRS was performed and yielded one factor, which was consistent with Fisher and Chen's findings. All ten items loaded on one factor and accounted for $59.1 \%$ of the variance. As alleged, the FDRS is also unidimensional in our Spanish sample. Cronbach's alpha on the FDRS was .93 for all men $(n=$ $189)$ and .82 for all women $(n=223)$, which indicates that the FDRS is internally consistent.

Sexual Experiences Survey. For the second section of the survey, we used the SES (Koss \& Oros, 1982), a tenitem, anonymous, self-report questionnaire for exploring SA and victimization from the age of fourteen by means of items about sexual intercourse associated with various degrees of coercion, threat, and force. Respondents were asked if they had experienced sexual intercourse or other sexual activities (oral or anal intercourse) when unwanted as a result of pressure, arguments, threats (verbal or physical), or some degree of physical force, or if they had ever been raped. During the actual administration, separate wordings were used for women and men. The female wording is presented in the following sample item (with male wording in brackets): "Have you ever had [engaged in] sexual intercourse when you [the woman] didn't want to because a man [you] used some degree of physical force (twisting your [her] arm, holding you [her] down, etc.) to make you [her]?" According to the items of the SES, male respondents can be only the perpetrators of $S A$, and female respondents, the victims of SA. The terms "rape," "victim," and "perpetrator" were avoided in order to reduce any bias that could be introduced, using instead neutral wordings and personal pronouns.

This section was administered after the date-rape vignette and FDRS to make certain that all students understood that the questions were about SA among acquainted individuals. The SES employs a dichotomous-choice format (yes or no) and if a subject answered yes to any item, then he or she was asked to quantify the number of occurrences of this specific experience. The text of all ten items of the SES (with female wording) can be found in Table 4, in the Results section.

Koss and Gidycz (1985) reported an internal consistency of .74 (for women) and .89 (for men) for the SES. A testretest mean reliability of $93 \%$ between administrations one week apart was found. The Pearson correlation between a woman's level of victimization based on self-report and her level of victimization based on responses to an interviewer several months later was .73. The Pearson correlation between a man's self-reported level of SA and that obtained in a posttest face-to-face interview several months later was .61. The internal consistency reliability (Cronbach's alpha) we obtained for the SES items was .57 and .43 , respectively, for women $(n=223)$ and men $(n=189)$, which is not an acceptable level. In all probability, this was due to the low prevalence rates on all ten items of the SES. The partition of the responses of students who did, versus those who did 
not, experience or perpetrate SA thus resulted in low item variance. These reliability figures did not affect our remaining statistical results and were merely meant for comparisons with prior and/or future studies. Contrary to our findings among Spanish students, American students answered affirmatively more often on all SES items (Koss et al., 1987), resulting in higher reliabilities (Koss \& Gidycz, 1985).

Help-Seeking Questionnaire. The women who answered one or more of the ten items of the SES affirmatively were requested to fill in a third section. We used a brief questionnaire by Ogletree (1993). Eleven items were designed to determine whether women who had been sexually victimized by an acquaintance, indeed sought help and, if so, from whom, and how soon after the assault. Help-seeking behavior was defined as "any communication about a troublesome event that is aimed at obtaining support, advice, or assistance in times of distress." Assistance could be sought from friends and relatives as well as from professional help agencies. This section used a dichotomous-choice format (yes or no). Table 6, which is presented in the Results section, shows which forms of help could be sought.

\section{Procedures}

Scoring Procedures. To determine whether a student accepted forced sex, we transformed the six-point scale of the FDRS to dichotomous responses, recoding scores 1, 2, and 3 as cmacceptable, and scores 4,5 and 6 as acceptable. According to this method, in this study, a student who responded "acceptable" (scores 4, 5, or 6) on at least one of the ten situations described in the FDRS, was considered as someone who accepts forced sex.

On the SES, Koss et al. (1987) originally categorized the most serious or severe types of aggression or assault. In their study, respondents were classified according to the severest form of SA or victimization that they reported having experienced - i.e., the four levels were: "sexual contact," "sexual coercion," "attempted rape," and "rape" (see Table 5). In our study, we also classifjed our respondents according to these four levels. The groups labeled "rape" (affirmative responses to items 8, 9, and/or 10, as well as to any lower-numbered items) and "attempted rape" (affirmative responses to items 4 and/or 5, but not to any higher numbered items) included individuals whose experiences met legal definitions of these crimes in the Spanish legislation. The group tabeled "sexual coercion" (affirmative responses to items 6 and/or 7 , but not to any higher numbered items) included subjects who had engaged in or experienced sexual intercourse subsequent to the use of menacing verbal pressure or the misuse of authority. No threats of forcc or direct physical force were used. The group labeled "sexual contact" (affirmative responses to items 1 , 2 , and/or 3, but not to any higher numbered items) consisted of individuals who had engaged in or experienced sexual behavior such as fondling or kissing but that did not involve attempted penctration, subsequent to the use of menacing verbal pressure, misuse of authority, threats of harm, or actual physical force.

\section{Statistical Analyses}

This study involved three independent variables: the participants' sex (male or female), their branch of study (psychology, economics, medicine, literature, and natural science), and year of study (first-year or fourth-year). All three independent variables were between-subject variables. This resulted in a $2 \times 5 \times 2$ factor design.

The study involved three dependent variables: acceptabilityratings of forcible sexual relationships, experiences with $\mathrm{SA}$, and the kind of help that may have been sought.

Exploration of the relationships was done by chi-square analysis and ANOVA. In the ANOVA, the six-point scale responses were used.

The reliability of the FDRS and the SES is based on American university or high-school students. We wished to compare these results with those obtained using responses by a Spanish student population. For this, we used item total-correlations.

Table 1

Distribution of Students who completed all the Questionnaires

\begin{tabular}{lcccc}
\hline Branch of Study & \multicolumn{2}{c}{ Women } & & Mcn \\
\hline Psychology & $1^{\text {st }}$ year & $4^{\text {th }}$ year & $1^{\text {st }}$ year & $4^{\text {th }}$ year \\
Economics & 22 & 24 & 18 & 18 \\
Literature & 24 & 15 & 18 & 20 \\
Medicine & 25 & 23 & 25 & $4^{b}$ \\
Natural Science & 24 & 22 & 23 & 19 \\
\hline
\end{tabular}

Note. ${ }^{a} N=412 .{ }^{b}$ Due to unexpected early termination of the academic year, in this class no more participants were available. 
Table 2

Number and Percentages of Students who Accept Forced Sex and Differences as a Function of Sex on FDRS

\begin{tabular}{|c|c|c|c|c|c|}
\hline \multirow{2}{*}{ Situation } & \multicolumn{2}{|c|}{ Women $(n=223)$} & \multicolumn{2}{|c|}{ Men $(n=189)$} & \multirow[b]{2}{*}{$x^{2}(d f=1)$} \\
\hline & $N$ & $\mathscr{R}$ & $\mathrm{N}$ & $\%$ & \\
\hline 1. & 5 & 2.2 & 6 & 3.2 & 0.36 \\
\hline 2. & 8 & 3.6 & 16 & 8.5 & $4.44^{*}$ \\
\hline 3. & 2 & 0.9 & 14 & 7.4 & $11.62^{* * * *}$ \\
\hline 4. & 0 & 0 & 6 & 3.2 & $7.18 * *$ \\
\hline 5. & 3 & 1.3 & 8 & 4.2 & 3.28 \\
\hline 6. & 2 & 0.9 & 5 & 2.6 & 1.87 \\
\hline 7. & 5 & 2.2 & 20 & 10.6 & $12.69 * * *$ \\
\hline 8 & 0 & 0 & 3 & 1.6 & 3.57 \\
\hline 9. & 5 & 2.2 & 13 & 6.9 & $5.26^{*}$ \\
\hline 10. & 2 & 0.9 & 13 & 6.9 & $10.5 I^{* *}$ \\
\hline
\end{tabular}

Note. FDRS = Forcible Date Rape Scale.

$* p<.05, * * p<.01, * * * p<.001$.

Results

\section{Attitudes about Acceptance of Forced Sex}

Table 2 shows the results (in actual numbers and percentages) of the responses of all male and female students in all ten circumstances of the FDRS. Among all male students $(n=189), 17.5 \%$ reported that it was acceptable for a boy to force sex on a girl in one or more of the ien hypothetical situations. This percentage dropped to $6.3 \%$ among all female students $(n=223)$. On the FDRS, all male students accepted forced sex more than all their female counterparts, $\chi^{2}(1, N=412)=9.62, p=.0021$. Among first-year students, more than one fifth (22.2\%) of the males $(n=109)$ accepted forced sex in one or more circumstances versus $5.1 \%$ of all the females $(n=118)$. First-year males accepted forced sex more than their female counterparts, $\chi^{2}$ $(1, N=227)=14.39, p=.00015$. Among fourth-year students, $11.1 \%$ of the males $(n=81)$ accepred forced sex versus $7.7 \%$ of the females $(n=104)$. Fourth-year males, however, did not accept forced sex significantly more than fourth-year females, $\chi^{2}(1, N=185)=.63779, p=0.42451$.

The acceptance of forced sex according to sex, branch of study, and year of study is presented in Table 3 . The percentage of acceptance of forced sex ranged from $44 \%$ (first-year male literature students) to $0 \%$ in several other branches of study. First-year male literature students were significantly more likely to respond that it was acceptable for a boy to force sex on a girl in one or more situations than were their female counterparts, $\chi^{2}(1, N=50)=8.42, p=$ .0037 . This was also the case for first-year medicine students, with males expressing more acceptance of forced sex than females, $\chi^{2}(1, N=47)=4.56, p=.0327$. Other group comparisons revealed no statistically significant differences.

At group level, male students $(n=189)$ accepted forced sex in situations two, three, four, seven, nine, and ten significantly more than females $(n=223)$ did (see Table 2 and Appendix B). Forced sex was most acceptable among

Table 3

Percentages of Students who accept Forced Sex according to Sex, Branch and Year of Study ${ }^{a}$

\begin{tabular}{lcccc}
\hline Branch of Study & & Women & $1^{\text {st }}$ year $\%$ & $4^{\text {Men }}$ \\
\hline Psychology & 0 & $1^{\text {st }}$ year $\%$ & 11.1 & 5.6 \\
Natural Science & 4.3 & 15.0 & 4.2 & 20.0 \\
Economics & 12.5 & 6.7 & 33.3 & 15.0 \\
Literature & 8.0 & 13.0 & 44.0 & 0 \\
Medicine & 0 & 4.5 & 17.4 & 5.3 \\
\hline
\end{tabular}

Nofe. "Percentages in actual numbers of Table!. 
all males when "they have had sex before" (situation 7) and least acceptable when "she gets drunk or high and passes out" (situation 8). First-year male and female students ( $n=$ 109 and 118 , respectively) differed significantly in the same six situations, as did all male and female subjects, although the most significant differences were found in situations seven and ten, $p<.005$. Among the fourth-year students, males and females ( $n=81$ and 104 , respectively) differed only in situations three and seven, $p<.05$, despite there being no overall statistically significant difference. Comparison of the females (first-year versus fourth-year) did not reveal any statistical differences in any of the ten imaginary circumstances. Comparison of the males revealed some differences between the first-year students ( $n=109$ ) and fourth-year students $(n=81)$ in situations two, nine, and ten, $p<.05$. However no overall statistically significant difference was found in this group.

To test these effects in more detail, an ANOVA was carricd out, in which acceptance of forced sex was used as the dependent variable (with the 6-point scale format), with sex, year of study, experience with SA, and branch of study as independent variables. Main effects, as well as two- and

Table 4

Sexual Experiences Survey (Koss \& Oros, 1982) and Percentages of Subjects who Experienced Described Sexual Behaviors and Means and Standard Deviations of Amount of Sexual Experiences from the Age of 14

\begin{tabular}{|c|c|c|c|c|c|c|}
\hline \multirow{2}{*}{ Sexual Behavior } & \multicolumn{3}{|c|}{ Women $(n=223)$} & \multicolumn{3}{|c|}{$\operatorname{Men}(n=189)$} \\
\hline & $\%$ & $M$ & $S D$ & $\%$ & $M$ & $S D$ \\
\hline $\begin{array}{l}\text { 1. Have you given in to sex play (fondling, kissing, or petting, but not intercourse) } \\
\text { when you didn't want to because you were overwhelmed by a man's continual } \\
\text { arguments and pressure? }\end{array}$ & 28 & 2.2 & 2.1 & 19 & 4.1 & 10.3 \\
\hline $\begin{array}{l}\text { 2. Have you had sex play (fondling, kissing, or petring, but not intercourse) } \\
\text { when you didn't want to because a man used his position of authority (boss, } \\
\text { teacher, camp counselor, supervisor) to make you? }\end{array}$ & 4 & 1.3 & 0.5 & 2 & 1.5 & 0.6 \\
\hline $\begin{array}{l}\text { 3. Have you had sex play (fondling, kissing, or petting, but not intercourse) } \\
\text { when you didn't want to because a man threatened or used some degree of } \\
\text { physical force (twisting your arm, holding you down, etc.) to make you? }\end{array}$ & 6 & 1.3 & 0.5 & 1 & 2.5 & 0.7 \\
\hline $\begin{array}{l}\text { 4. Have you had a man attempt sexual intercourse (get on top of you, attempt } \\
\text { to insert his penis) when you didn't want to by threatening or using some } \\
\text { degree of force (twisting your arm, holding you down, etc.), but intercourse } \\
\text { did not occur? }\end{array}$ & 5 & 1.6 & 1.2 & 1 & 1.0 & - \\
\hline $\begin{array}{l}\text { 5. Have you had a man attempt sexual intercourse (get on top of you, attempt } \\
\text { to insert his penis) when you didn't want to by giving you alcohol or drugs, } \\
\text { but intercourse did not occur? }\end{array}$ & 2 & 1.5 & 0.6 & 3 & 3.8 & 4.3 \\
\hline $\begin{array}{l}\text { 6. Have you given in to sexual intercourse when you didn't want to because } \\
\text { you were overwhelmed by a man's continual arguments and pressure? }\end{array}$ & 8 & 3.4 & 2.9 & 5 & 2.2 & 1.3 \\
\hline $\begin{array}{l}\text { 7. Have you had sexual intercourse when you didn't want to because a man } \\
\text { used his position of authority (boss, teacher, camp counselor, supervisor) to } \\
\text { make you? }\end{array}$ & 0 & - & - & 1 & 2.0 & 1.3 \\
\hline $\begin{array}{l}\text { 8. Have you had sexual intercourse when you didn't want to because a man } \\
\text { gave you alcohol or drugs? }\end{array}$ & 1 & 1.0 & - & 1 & 1.0 & - \\
\hline $\begin{array}{l}\text { 9. Have you had sexual intercourse when you didn't want to because a man } \\
\text { threatened or used some degree of physical force (twisting your arm, holding } \\
\text { you down, etc.) to make you? }\end{array}$ & 1 & 2.3 & 2.3 & 0 & - & - \\
\hline $\begin{array}{l}\text { 10. Have you had sex acts (anal or oral incercourse or penetration by objects } \\
\text { other than the penis) when you didn't want to because a man threatened or } \\
\text { used some degree of physical force (twisting your arm, holding you down, } \\
\text { etc.) to make you? }\end{array}$ & 1 & 5.0 & 5.7 & 1 & 1.0 & - \\
\hline
\end{tabular}


Table 5

Prevalence-Rate Percentages of Sexual Aggression (Men) and Victimization (Women) from Age 14

\begin{tabular}{lcccc}
\hline \multirow{2}{*}{ Aggression or Victimization Level } & \multicolumn{2}{c}{ Women $(n=223)$} & \multicolumn{2}{c}{ Men $(n=189)$} \\
\cline { 2 - 5 } & Tabulated $^{n}$ & Untabulated $^{b}$ & Tabulated $^{n}$ & Untabulated $^{b}$ \\
\hline Sexual contact & 19.7 & 31.5 & 15.3 & 21.2 \\
Sexual coercion & 5.8 & 7.6 & 5.3 & 5.8 \\
Attemped rape & 4.5 & 5.8 & 2.1 & 3.7 \\
Rape & 3.2 & 3.2 & 1.6 & 1.6 \\
\hline
\end{tabular}

Note. ${ }^{a}$ Respondents are classified according to the most severe type of SA or victimization.

$b$ The percentages of persons who reported each individual act of SA or victimization.

three-way interactions, were examined. The results showed a strong main effect for sex, $F(1,408)=8.799, p=.003$, with men being more accepting than women. A second main effect was found for branch of study, $F(4,408)=3.259, p$ $=.012$, with more acceptance of SA in economics, natural science, and literature. The interaction of year of study and experience with SA was statistically significant, $F(1,408)$ $=5.556, p=.019$, with acceptance of SA higher among the first-year students who had had experience with SA. A threeway interaction of sex-year-experience with SA was also revealed, $F(1,408)=7.971, p=.005$, with the acceptance of SA higher among the first-year male students with SA experience. Although experience with SA showed a tendency to be related to the acceptance of forced sex, this was not statistically significant, $F(1,408),=3.499, p=.062$.

\section{Prevalence of Sexual Aggression or Victimization}

The response frequencies for each item of the SES are presented in Table 4 . We found that $33.2 \%(n=74)$ of the women respondents had been victimized in some way and $24.3 \%(n=46)$ of the men admitted involvement in some form of SA. The frequencies of victimization ranged from $0 \%$ of women who reported unwanted sexual intercourse subsequent to misuse of the man's authority, to $28 \%$ who reported unwanted sexual contact subsequent to verbal pressure. The frequency with which men reported having perpetrated each form of SA ranged from $0 \%$ of men reporting obtaining sexual intercourse by threatening or using some degree of physical force, to $19 \%$ of men who indicated that they had obtained sexual contact (through the use of verbal pressure). Item response frequencies and the means and standard deviations for the number of times that a behavior was reported, are shown in Table 4 .

Respondents were classifjed according to Koss et al.'s (1987) method of scoring; i.e., the highest degree of sexual victimization or aggression reported by the student. That is, we tabulated the frequencies for each of the four classifications. More specifically, a respondent who answered items one ("sexual contact") and eight ("rape") affirmatively would only be included in the "rape" classification. In this way, we were able to calculate for each classification the exact number of students who had had this kind of experience. As a result of this scoring method, the most serious sexual victimization experienced by the women was: sexual contact for $19.7 \%$; sexual coercion for $5.8 \%$; attempted rape for $4.5 \%$; and rape for $3.2 \%$. The most extreme level of $S A$ perpetrated by the men was: sexual contact for $15.3 \%$; sexual coercion for $5.3 \%$, attempted rape for $2.1 \%$; and rape for $1.6 \%$.

However, we also calculated the total number of students who gave affirmative responses for each of the four classifications, which appears in the untabulated column of Table 5. Table 5 shows the prevalence rates of tabulated and untabulated scorings for $\mathrm{SA}$ and victimization.

Among the male respondents who had engaged in sexually aggressive acts, $43(19.5 \%)$ indicated they had perpetrated only one specific sexual aggressive act (i.e., one affirmative response on the SES); $18(8.1 \%)$ admitted having been involved in two different forms of sexual aggressive acts (i.e., two affirmative responses on the SES); and 12 $(5.5 \%)$ in three or more different forms of sexual aggressive acts (i.e., three or more affirmative responses on the SES). Among the victimized women, $33(17.5 \%)$ had experienced one specific unwanted sexual act; $11(5.8 \%)$ two unwanted sexual acts; and $2(1 \%)$ had experienced three or more unwanted sexual activities.

Table 6

Victim Help-Seeking Source

\begin{tabular}{lrr}
\hline Source & $n$ & $\%$ \\
\hline Friend & 22 & 75.9 \\
Counselor/therapist & 2 & 6.9 \\
Police & 3 & 10.3 \\
Rape crisis center & 1 & 3.4 \\
Parent(s) & 5 & 17.2 \\
Other relative & 11 & 37.9 \\
Physician/hospital & 3 & 10.3 \\
\hline
\end{tabular}

Note, ${ }^{a} \mathrm{n}=29$, although the sum of the frequencies is 47 , because some subjects help at several sources. 


\section{Help-Seeking Behavior}

Table 6 shows the number of women who sought hejp and from which sources. The results of SES revealed that $74(33.2 \%)$ of the 223 women responded affirmatively to at least one item and are therefore considered victims of some form of SA. Of the 74 women who had been victimized, $13(17.6 \%)$ indicated that they did not seek any help after the incident, whereas 29 (39.2\%) did seek help, and $32(43.2 \%)$ did not answer this item.

Of the 29 women who sought help, most of them went to several sources for help. Within this group, $22(75.9 \%)$ asked a friend for help, and 11 (37.9\%) sought help from a relative. Only $2(6.9 \%)$ sought help from a counselor or therapist, and $3(10.3 \%)$ went to the police for help. Furthermore, 5 women (17.2\%) turned to a parent, $3(10.3 \%)$ went to a hospital or a physician, and $1(3.4 \%)$ went to a rape crisis center. All those who went to a counselor or therapist, the police, a hospital, a physician, or a rape crisis center also sought help from a relative or friend.

Seven of the 29 victims who sought help $(24.1 \%)$ did not answer the item about the time-lapse between the SA and the help-seeking behavior. Ninetcen ( $86.4 \%$ ) of the 22 victims who did answer this item sought help within two weeks after the incident took place; $3(13.6 \%)$ indicated they did so within a year, no woman sought help when more than a year had gone by.

\section{Discussion}

In the first place, $17.5 \%$ of all male students versus $6.3 \%$ of all female students believed that it was acceptable for a boy to force sex on a girl in one or more situations. Firstyear male students $(22.2 \%)$ expressed the most acceptance of forced sex, followed by fourth-year males $(11.1 \%)$, fourthyear females $(7.7 \%)$, with first-year females $(5.1 \%)$ being the least accepting. A tentative explanation for the difference in acceptance of SA between first- and fourth-year males is that the first-year males are more likely to believe in traditional sexual scripts than do fourth-year malcs (see LaPlante, McCormick, \& Brannigan, 1980). These male students may believe in, and become sexually excited by, the idea that their partners will resist their advances at first and then be overcome with passion and willingly and even enthusiastically take part in sexual intercourse (Check \& Malamuth, 1983; Russell, 1984; Shotland, 1992). When the female withholds sexual intercourse these males may feel they have been treated unfairly and therefore believe that aggressive behavior is justified. Previous studies have reported that men who accept stereotypical myths about rape, who condone violence against women, who hold adversarial sexual beliefs, or accept traditional sex role attitudes tend to show greater tolerance towards rape, to blame rape victims more, and to report a greater likelihood of raping if they could be assured that no one would know (Burt, 1980; Check \& Malamuth, 1983; Malamuth, 1981; Muehlenhard et ai., 1985). On the other hand, first-year female students plausibly hold more conservalive sexual values than do their fourth-year counterparts. who may be more liberal insofar as concerns sex roles. This explanation receives some empirical support from LaPlante et al. (1980), who found that many young women enact, as well as believe in, the traditional sexual script, which dictates that women should either passively acquiesce to their dates' sexual advances, or else use any strategy to influence a date so as to avoid sexual intercourse (Peplau, Rubin, \& Hill, 1977). In spite of the acceptance of sexual scripts expressed by first-year students of both sexes (in differing degrees), it appears that university education produces a twofold change: in women, toward "liberalism," and in men, toward "more respect."

There were signiftcant sex differences in attitudes in six situations of the FDRS, with males being more tolerant of $S A$ in all situations. The most pronounced differences were in situations "when the couple had previously had sex" (situation 7) and "when they had dated for a long time" (situation 3). Other situations in which male and female students showed significant differences were: "when she has had sex with one of his friends" (situation 10); "when he buys her dinner or pays for a movie" (situation 4); "when she gets him so sexually excited, he cannot stop" (situation 2 ); and "when she agrees to go home with him" (situation 9). It is striking that both male and female Spanish students hardly accept the so-called "token-no" myth (i.e., believing a woman desires sex even after verbally saying "no"), in contrast to the findings among American college and highschool students in the United States (Benson et al., 1992; Muehienhard et al., 1985; Muchlenhard \& Hollabaugh. 1988; Rapaport \& Burkhart, 1984). It seems plausible that rape myths are not uniformly and widely accepted in the Western culture. Rather, there is evidence in this study of various subcultural norms and attitudes.

Furthermore, it appears that the acceptance of forced sex is significantly related to the branch of study, but also to the interaction of sex, ycar of study, and experience with SA. The above results indicate that women in the economics, natural science and literature branches of study are at greater risk of becoming viclims of SA than women from other branches (psychology and medicine), although causal relations of SA cannot be inferred on the basis of correlational data alone. One could speculate that the reason why women from the psychology and medicine branches differ in their acceptance of SA may lie in the "nature" of these studies, which could have a self-selective effect. These female students may reject aggression beforehand (c.g., SA) and then choose a study with higher humanitarian-helping content. Another possible explanation of why male students differ significantly in their acceptance of forced scx with respect to their branch and year of study may be that in some branches and years of study, more involvement in peer groups 
occurs which may reinforce views of women as being highly sexualized objects. A highly intensive male-peer environment may promote narrow, stereotypical conceptions of masculinity and may emphasize violence, force, and competition in relationships. An important goal for future research is to examine more extensively the group norms, beliefs, and lifestyles of students in all branches and years of study.

In the second place, SA among Spanish students who are acquainted with each other appears to be common. In the present study, $33.2 \%$ of the women and $24.3 \%$ of the men reported having been in a situation where sex had been forced, from the age of fourteen; the women reported fondling or kissing after verbal pressure (28\%) as the most frequent unwanted sexual activity, followed by sexual intercourse after verbal pressure $(8 \%)$. Of all the women, $7.7 \%$ reported an experience that met the Spanish legal definition of attempled and completed rape, versus $3.7 \%$ of all men. These percentages are below the rates listed in American literature but are still pervasive and imposing. At the Autonomous University of Madrid, over 17,000 female students were enrolled at the time this research was conducted (academic year 1995-96), which could mean that more than 1,300 women have experienced an attempted or completed rape. The different prevalence-rate figures between male and female students does not necessarily imply that men have a tendency to deny or under-report their sexual aggressive behavior, but simply may be due to the fact that perpetrators, as well as victims, of SA can also be nonstudents.

In the third place, our results also revealed that only a small percentage of the women who had experienced unwanted sexual activities sought professional help (39.2\%). Most victims turned to a friend or relative to obtain help. Very few women went to a counselor, a therapist, the police, a physician or a rape crisis center. This finding is in accordance with prior research where victims of SA seldom reported the incidents to official sources (Koss et al., 1987; Warshaw, 1988). Several researchers have suggested a number of reasons to explain why women who experience sexual victimization neither seck help nor report the incident to the authorities. They found that the acquaintance element is a powerful determinant of help-seeking behavior (Koss et al., 1988; Wilson \& Durrenberger, 1982; Yegdis, 1986). There seems to be an inverse relationship between the victim-offender relationship and help-seeking. The better acquainted the victim is with the offender, the less likely she is to seek help. The degree to which the woman identifies a sexually coercive experience as sexual assault is another factor in help-seeking. As situations increasingly resemble the classic rape scenario, women are more likely to seek help. The classic rape scenario most often involves a stranger, includes the use of physical force, and results in observable physical injuries. SA with an acquaintance docs not match the stereotype that people have of SA (i.e., strangers in dark alleys) and, thus, people are less likely to identify it as SA.
In the fourth place, in contrast to the findings of Malamuth (1981), Rapaport and Burkhart (1984), and Koss et al. (1985), we did not find a direct relation between attitudes supporting SA and actual experience of SA. Data analyses showed that the students who had experienced some form of SA, versus those who had not, did not differ significantly in their acceptance of forced sex. This is not surprising, as our data revealed lower levels of acceptance of SA and fewer experiences with SA among Spanish university students, which may explain the lack of significant differences in our sample.

In summary, our results indicate major sex differences in Spanish students' attitudes towards males forcing sex on females. Sex differences in specific situations were of particular interest to the authors as, in these circumstances, unwanted sexual activities may be elicited more easily. We believe that various assumptions and expectations about sexual interaction between men and women may contribute to SA, particularly in those situations where these assumptions and expectations are quite extended. Differences in attitudes emphasize the need for better understanding and more direct communication between males and females. Because this study involved primarily Spanish students from one university campus, our findings can only be generalized with caution. It is for further replication studies to determine whether SA is highly prevalent among general, nonclinical, and noncollege population samples of Spanish men and women.

The results of this study point out the necessity of increasing awareness about SA among Spanish university students. The results also document the need for prevention programs and counseling for all Spanish women who are sexually victimized. The campus health center at the Autonomous University of Madrid should make every effort to implement workshop programs to encourage students to adopt attitudes, beliefs, and behaviors promoting healthy dating.

The data obtained show that many college women are at risk of being persuaded to have unwanted sex and highlight women's inability to refuse comfortably. The majority of Spanish women in this study who had experienced unwanted intercourse or other unwanted sexual contacts were coerced by continuous arguments and pressure. This has implications for education programming in the area of communication. Through appropriate classes, workshops, seminars, and counseling sessions, college-student personnel must address communication issues and offer training in effective communication skills. However, the causes of sexual assault are complex and involve a wide range of men's experiences, attitudes, and cognitions.

\section{References}

Abbey, A. (1991). Acquaintance rape and alcohol consumption on college campuses: How are they linked? Joumal of American College Health, 39, 165-169. 
Aizenman, M., \& Kelley, G. (1988). The incidence of violence and acquaintance rape in dating relationships among college men and women. Joumal of College Student Development. 29, 305-311.

Benson, D., Charlton, C. \& Goodhart, F. (1992). Acquaintance rape on campus: A literature review. Joumal of American College Health, 40, 157-165.

Berkowitz, A.B. (1992). College men as perpetrators of acquaintance rape and sexual assault: A review of recent research. Joumal of American College Health, 40, 175-181.

Burgess, A.W., \& Holmstrom, L.L. (1974). Rape trauma syndrome. American Joumal of Psychiatry, 131, 981-986.

Burt, M.R. (1980). Cultural myths and support for rape. Joumal of Personality and Social Psychology, 38, 217-230.

Check, V., \& Malamuth, N.M. (1983). Sex role stereotyping and reactions to depictions of stranger versus acquaintance rape. Joumal of Personality and Social Psychology, 45, 344-356.

Davis, T.C., Peck, G.Q., \& Storment, J.M. (1993). Acquaintance rape and the high-school student. Joumal of Adolescent Health, 14, 220-224.

Dull, R.T., \& Giacopassi, D.J. (1987). Demographic correlates of sexual and dating attitudes. Criminal Justice and Behavior, 14, 175-193.

Ellis, G.M. (1994). Acquaintance rape. Perspectives in Psychiatric Care, 30, 11-16.

Fischer, G.J. (1986). College student attitudes toward date rape. I: Cognitive predictors. Archives of Sexual Behavior, 15, 457-466.

Fischer, G.J., \& Chen, J. (1994). The Attitudes toward Forcible Date Rape Scale: Development of a measurement model. Joumal of Psychopathology and Behavioral Assessment, 16, 33-5I.

Frinter, M.P., \& Rubinson, L. (1993). Acquaintance rape: The influence of alcohol, fraternity membership and sports tean membership. Journal of Sex Education and Therapy, 19, 272284.

Giarusso, R.. Johnson, P.B., Goodchilds, J.D., \& Zellman, G. (1979). Adolescent cues and signals: Sex and assault. Paper presented at meetings of the Westem Psychological Association, San Diego, CA.

Goodchilds, J.D., Zellman, G., Johnson, P.B., \& Giarusso, R. (1988). Adolescents and their perceptions of sexual interaction outcomes. In A.W. Burgess (Ed.), Rape and Sexual Assault 7 (pp. 245-270). New York: Garland.

Gross, A.E. (1978). The male role and heterosexual behavior. Journal of Social Issues, 34, 87-107.

Koss, M.P. (1988). Hidden Rape: Sexual aggression and victimization in a national sample in higher education. In A.W. Burgess (Ed.), Rape and Sexual Assault /I (pp. 3-25). New York: Garland.

Koss, M.P., Dinero, T.E., Seibel, C.A., \& Cox, S.L. (1988). Stranger and acquaintance rape: Are there differences in the victim's experience? Psychology of Women Quarterly, 12, 1-12.

Koss, M.P., \& Gidycz, C.A. (1985). Sexual Experiences Survey: Reliability and validity. Joumal of Consulting and Clinical Psychology, 53, 422-423.
Koss, M.P., Gidyez, C.A., \& Wisniewski, N. (1987). The scope of rape: Incidence and prevalence of sexual aggression and victimization in a national sample of higher education students. Joumal of Consulting and Clinical Psychology, 55, 162-170.

Koss, M.P., Leonard, K.E., Beezley, D.A., \& Oros, C.J. (1985). Nonstranger sexuat aggression: A discriminant analysis of the psychological characteristics of undetected offenders. Sex Roles, 12. $981-992$.

Koss, M.P., \& Oros, C.J. (1982). Sexual Experiences Survey: A research instrument investigating sexual aggression and victimization. Joumal of Consulting and Clinical Psychologv, 50, 455-457.

LaPlante, M.N., McComick, N., \& Brannigan, G.G. (1980). Living the sexual script: College students' views of influence in sexual encounters. The Journal of Sex Research. 16, 338-355.

Lundberg-Love, P., Geffner, R. (1989). Date rape: Prevalence, risk factors and a proposed model. In M.A. Pirog-Good \& J.E. Stets (Eds.), Violence in dating relationships: Emerging social issues (pp.135-148). New York: Praeger.

Malamuth, N.M. (1981). Rape proclivity among males. Joumal of Social Issues, 37, 138-157.

Malamuth, N.M. (1983). Factors associated with rape as predictors of laboratory aggression against women. Joumal of Personality and Social Psychology, 45, 432-442.

Margolin, L., Miller, M., \& Moran, P.B. (1989). When a kiss is not just a kiss: Relating violations of consent in kissing to rape myth acceptance. Sex Roles, 20, 231-243.

Muehlenhard, C.L., Friedman, D.E., \& Thomas C.M. (1985). Is date rape justifiable? The effects of dating activity, who initiated, who paid, and men's attitudes towards women. Psychology Women Quarterly; 9, 297-310.

Muehlenhard, C.L., \& Hollabaugh, L.C. (1988). Do women sometimes say no when they mean yes? The prevalence and correlates of women's token resistance to sex. Journal of Personality and Social Psychology, 54, 872-879.

Muehlenhard, C.L., \& McFall, R.M. (1981). Dating initjation from a woman's perspective. Behavior Therapy, 12, 682-691.

Ogletree, R.J. (1993). Sexual coercion experience and help-seeking behavior of college women. Journal of American College Health, 4I, 149-153.

Peplau, L.A., Rubin, Z., \& Hill, C.T. (1977). Sexual intimacy in dating relationships. Journal of Social 1ssues, 3, 86-109.

Peterson, S.A., \& Franzese, B. (1987). Correlates of college men's sexual abuse of women. Journal of College Student Development, 28, 223-228.

Quackenbush, R. (1991). Attitudes of college men's toward women and rape. Joumal of College Student Development, 32, 376-377.

Rabkin, J.G. (1979). The epidemiology of forcible rape. American Journal of Orthopsychiatry, 49, 634-647.

Rapaport, K. \& Burkhart, B. (1984). Personality and attitudinal characteristics of sexually coercive college males. Jommal of Abnomal Psychology, 93, 216-221.

Resick, P.A., Calhoun. K.S., Atkeson, B.M., \& Ellis, E.M. (1981). Social adjustment in victims of sexual assault. Joumal of Consulting and Clinical Psychology, 49, 705-712. 
Russell, D.E.H. (1984). Sexual exploitation: Rape, child sexual abuse, and workplace harassment. Beverly Hills, CA: Sage.

Shotland, R.L. (1992), A model of the causes of date rape in developing and close relationships. Review of Personality and Social Psychology, 10, 247-270.

Warshaw, R. (1988). I never called it rape: The Ms. repont on recognizing, fighting, and sumving date rape and acquaintance rape. New York: Harper \& Row

Weis, K., \& Borges, S.S. (1973). Victimology and rape: The case of the legitimate victim. Issues in Criminology, 8, 71-115.
Wilson, W., \& Durrenberger, R. (1982). Comparison of rape and attempted rape victims. Psychiatrical Reports, 50, 198207.

Yegdis, B.L. (1986). Date rape and other forced sexual encounters among college students. Journal of Sex Education Therapy, $12,51-54$

Received June 1, 1997

Revision received June 5, 1999

Accepted July 1, 1999 


\section{APPENDIX A}

Date-rape vignette (adapted from Davis, Peck, \& Stormont, 1993)

Louis, 19, and Eva, 18, had been dating steadily for two years. One night at a party given by the faculty of the university, they had both been drinking heavily. They had a terrific time at the party, and they were sightly excited while doncing. On the way home, Louis pulls the car off onto a desented street. They proceed to kiss, and Eva allows Louis the usual "above the waist" touching. When he reaches between her legs, she says "No," as she always has, and, at this point, Louis usually stops touching her there and keeps on kissing her. This night Louis doesn't stop. Over Eva's cries of "No, no!" he continues to take her clothes off and forces her to have sex with him. 


\section{APPENDIX B}

Forcible Date Rape Scale (Giarusso et al., 1979)

"It's OK for a boy to force a girl to have sex with him if..."

1. She says yes at first, but then changes her mind and says no.

2. She gets him so sexually excited, he can't stop.

3. They have dated for a really long time.

4. He buys her dinner or pays for a movie.

5. She lets him touch her above the waist.

6. She's wearing/revealing sexy clothing.

7. They have had sex before.

8. She gets drunk or high and passes out.

9. She agrees to go home with him.

10. She has had sex with one of his friends. 